\title{
Organizational stress management
}

\author{
Managementul stresului organizaţional
}

Professor Maria CARACOTA DIMITRIU, Ph.D. The Bucharest Academy of Economic Studies, Romania e-mail: maria.dimitriu@inde.ro

Andrea MITOVSKI, Ph.D. Student The Bucharest Academy of Economic Studies, Romania e-mail: deina_yu@yahoo.com

\begin{abstract}
There are plenty of general problems that people at work worry about increasing job competition, globalization, terrorism, annual appraisals, financial crisis, even new technology. Beside these, employees are put under pressure to meet sales targets, attend meetings on time, fit in with changes in organization by learning and following up new procedures. All these can result different levels of stress. Nowadays, working stress is the fastest growing cause of absence from work. Inefficient management, lack of decisionmaking by management, excessive working hours, uncertainty as to future employment prospects and the pressure of the job are some of the causes of stress described by employees. Therefore, employers should consider organizational stress as a serious problem and they must take measures to prevent employees suffering stress arising from their work. It can negatively influence the productivity and competitiveness of the organization, and can also increase health insurance costs.
\end{abstract}

Keywords: stress management, organizational stress, total working system

\section{Rezumat}

Există o mulțime de probleme generale care îi preocupă pe oameni la locul de muncă - permanenta creştere a competitivității în muncă, globalizarea, terorismul, creşterile de prețuri anuale, criza financiară, chiar şi tehnologia. Pe lângă acestea, angajații sunt puşi sub presiunea de a respecta țintele vânzărilor, de a participa la întâlniri la timp, de a se conforma schimbărilor în cadrul organizației prin învățare şi urmărind proceduri noi. Toate acestea pot aduce la diferite stadii de stres. In zilele de azi, stresul organizațional este cauza în cea mai mare creştere, care provoacă absența de la locul de muncă. Managementul ineficient, lipsa de luarea deciziilor de către management, ore de muncă peste program, nesiguranța pentru perspectiva de angajare $\hat{\imath}$ viitor, preum şi presiunea din partea serviciului, sunt unele dintre cauzele ale stresului explicate de angajați. De aceea, angajatorii trebuie să considere stresul organizațional ca pe o problemă serioasă şi trebuie să ia măsuri pentru prevenirea stresului apărut la locul de 
muncă, care afectează angajații. Stresul poate avea influență negativă asupra productivității şi a competitivităţii organizației, şi de asemenea poate creşte costurile de asigurarea sănătății.

Cuvinte-cheie: managementul stresului, stresul organizațional, sistemul total de lucru

JEL Classification: J28, J81, M12, M54

\section{Introduction}

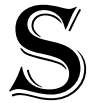

tress within an organization is managed at two levels: al organizational level by organizational arrangement, and at personal's level by individual's arrangement. Organizational arrangement examines the structure of the relationships between stressors and strains, without taking consideration on individual differences. This means that job design and control or decision interact to influence health. Personal arrangement focuses on the cognitive processes and emotional reactions based on individuals' interactions with their environment, so that items cannot be conceptualized as stressors independently of a person's reaction to them, because what is stressful for one person may not be stressful for another. Once a problem has been identified, specialists start identification and development of solutions, by training for employers and employees, managers, provision of information, timeframe for review, in order to develop awareness of stress and its management, and to educate employers about how they can limit organizational stress. Costs caused by work-related stress amount about 20billion EUR yearly (Guidance on Work-Related Stress, 2002).

\section{Organizational arrangement - organizational stress management at organizational level}

Organizational arrangement strategy for prevention, reduce, and relieve of stress at workplace represents properly rearrangement of working conditions within an organization through job design, and creation of healthy workplace. Positive effects of this sort of intervention should be in long-run. It is created for employers, for organization, in order to create better and satisfying conditions. It contains educational trainings and sets of arrangements. Employers and organization will reach within the organization regarding to job design, and healthy workplace environment standards by acknowledging and understanding time management, goal and work-roles, responsibility and authority, arrangements and ability, ambiguity and errors, meaning, stimulation and reward, beneficial support, and team building. They will also get know about environmental, socio-cultural, and lifestyle factors which influence and create organizational stress. Environmental factors refer to evaluation regarding ergonomic norms and standards, and application of these norms and standards. Socio-cultural factors refer to work-family balance, satisfaction with work, communication, emotional and social support, and moral at workplace. Life-style factors refer to breaks within working time, and health education. All of these should be done in order to prevent, relieve, and reduce stress.

Vol.12, Nr. 1 special/2009

Economia seria Management 
After setting organizational and person's arrangement, stress management control process will take place. This stress management control process includes identification of incidence, prevalence, severity and attendance of work-related stressor exposures and their causes and health consequences; analyze of organization and conditions of work in relation to the outcomes found, and finding out weather they are likely to be necessary, sufficient or contributory in causing work-stress and ill health related to it, whether they are accessible to change, and weather such changes are acceptable; design of an integrated package of interventions, and implementation of this integrated package of interventions in order to prevent work-related stress and to promote well-being and productivity; evaluation of outcomes of the interventions in terms of stressor exposures, stress reactions, incidence and prevalence of ill health, indicators of well-being, productivity with regard to the quality and quantity of goods or services, and costs and benefits in economic terms; all these mentioned above using personal stress questionnaire.

\section{Person's arrangement - organizational stress management at individuals' level}

At this level, in order to prevent, reduce and relieve stress, we have to take separately every person, according to its personality, historical events experienced, and to found stressors and solutions for stress for any person apart. Person's arrangement contains wide arranging types of interventions may thus be considered in "AV Stress Management Program", leaving the choice of the most effective combination to form person's arrangement according to specific features particular employee's situation. These arrangements consist of two possible types of interventions ranged from interventions aimed in Stress Prevention Program as primary intervention, and interventions aimed in Stress Reducing Program being secondary intervention.

In order to prevent stress between employees, these should be trained and informed about professional contentment including time and achievement management, communication and personality, and work and workplace organization. Employees should also be informed about health, about their free time, self-care skills, to which will be added trainings on hobby, nutrition, fitness, wellness, and massage. Beside these, anti-stress program should be promoted through education on identification of possible causes (sources, levels, and effects), as well as education on stress management and support. A preventive medical examination and medical examination is necessary. This will define level of stress affection on health. Each person that has established severe medical illness should be directed to further medical care. A person is analyzed as a whole, analyzing all of his potentials with problems. This would help to choose the most effective combination as the best possible form, containing following: autogenic training, mindfulness meditation, yoga or walking meditation, progressive muscular relaxation, transcendental meditation, biofeedback, music therapy, self-control meditation, paced respiration, deep breathing, Jacuzzi, swimming pool, hydro-massage, and occupational therapy. 


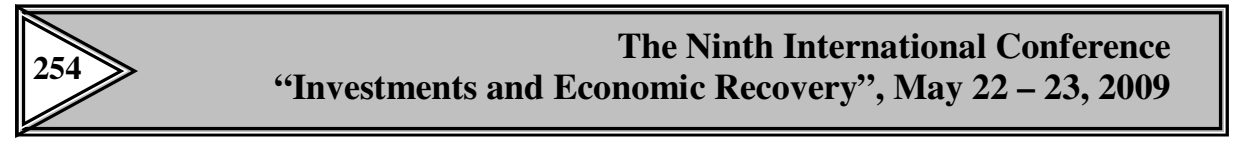

\section{Job design and delegation of work activities}

Job design contains norms and elements for creating secure working conditions, applying experience and knowledge of stressor impact at workplace, in order to prevent and reduce stress that influence employees. These norms and elements are represented by the following: beside a typical five-day-eight-hours work, it is recommend to use alternative work schedule that consists of flextime or compressed workweek; design work schedules to avoid conflict with demands and responsibilities unrelated to job; allow adequate time to perform activities satisfactorily; clarify organization's goals and values and adapt them to the worker's own goals and values; define work roles and responsibilities clearly; harmonize worker's responsibility and authority; ensure that assignments are compatible with the capabilities and resources of the worker, in order to avoid both over- and underload; adjust occupational physical settings to the workers' abilities, needs and reasonable expectations; avoid ambiguity in matters of job security and career development; appraise likely errors; design tasks to provide meaning, stimulation, a sense of completeness and an opportunity to use skills; promote reasonable reward for the effort and good job performance; beneficial support will help employees to balance the demands of work and family, offering flexible spending accounts, child care and elder care assistance, part-time work options and other facilities; and team-building. Approaches to job design are: job enlargement (adding more tasks of the same kind to an existing job, using the same skills a quantitative change in duties), job enrichment (adding a task that requires more knowledge, technical expertise, or responsibility, increasing individual development, by skill variety, task identity, task significant, autonomy, feedback - a qualitative change in duties), work flow rearrangement (job rotation (moving people horizontally into jobs with new tasks) and work modeling (moving people to add variety of tasks to repetitive jobs)), autonomous work groups (group member establishing working hours, schedules, rest breaks, selecting new members, evaluating present members, and initiating discharge of unsatisfactory performers), job sharing (two employees share a single job, usually on a parttime base), changes in work scheduling (increase the individual's flexibility in scheduling working hours), and supervisory training (delegating responsibilities to employees).

Delegation is a skill in management, especially in work overload. It is a skill of bringing other people's expertise to bear in your work, particularly in areas where you do not have the skills or temperament to do the best. One must learn to delegate parts of his work I order to be able to manage his increased workload, because there is a limit to the amount of work one can do on his own, especially under pressure, experiencing stress. The rest should be delivered to the organization. If someone do not delegate, he cannot progress in his career, because he will not be able to take more work. Transfer of responsibility develops staff, increasing their capability, and benefits the organization, and can also increase their role enjoyment. But it is important to retain a suitable level of control over the process and finished product.

Vol.12, Nr. 1 special/2009

Economia seria Management 


\section{Creating a healthy workplace, and total working system}

Healthy workplace can be created by adjustment of environmental, socio-cultural, and lifestyle factors, led by ergonomic researches of anthropometrical, physiological, sensor, and psychological characteristics of human organism and his behavior. Each factor has certain parameters and conditions that should be fulfilled. If these conditions are not satisfied, they will be imposed during changes through the organizational arrangement. Environmental factors that affect health at workplace are represented by: physical stressors (temperature, lighting, ventilation, humidity, noise (vibration), radiation, workplace design in any kind), and if necessary, to change the environment relating to chemical and biological working conditions. Socio-cultural factors related to healthy workplace represent: achieving a satisfactory balance between work and family commitments, training and development, satisfaction with work, positive communication and feedback, provide emotional and social support and help between fellow workers, ethical norms (promote tolerance, security and justice at the workplace). Lifestyle factors with impact on workplace health should be regulated through: smoking cessation programs, lunch brake, refreshment brakes in order to regenerate attention, healthy eating and weight control, personal hygiene measures, physical activity on a regular basis, healthy pregnancy, alcohol, drug and coffee abuse.

Total working system is important in design of working layouts, setting of work rates, arrangement of safe systems of work, and in prevention of stress. It takes into consideration human characteristics, environmental factors, man-machine interface, and total working system. Talking about human characteristic, people differences in physical and mental capacity are mostly remarked in case of the physical elements of body dimensions, strength and stamina, and psychological elements of learning, perception, personality, attitude, motivation and reactions to stimuli. Level of knowledge, training received, personal skills and work experience also directly influence the performance. Environmental factors directly affecting people health and their subsequent performance such as noise, vibration, extremes of temperature and humidity, and poor levels of lighting and ventilation, are called environmental stressors. There is a need to eliminate and control environmental stressors, working area layout, and amount of available individual workspace. Machines provide information to user through various forms of display. On the other hand, the user must ensure the correct and safe operation of the machine through a system of control. The control is executed by push-button, foot pedals or manual devices. Correct and safe operation of work equipment can be ensured by factors as location, reliability, ease of operation, distinction of controls, identification, ease of reading, sufficiency, meaning and compatibility of displays. High job performance can be achieved only with correct combination of all of these factors. How will human characteristics, tasks, man-machinery interface, and environmental factors affect total working system, describes ergonomics. It is a multidisciplinary study of the relationships between the person and the environment, describing how human being is affected by his environment, especially in the workplace, enhancing safety, productivity and quality of life. Job can be fitted to the person by evaluation and design of workplace, environments, job, tasks, equipment, and processes with human capabilities and interactions in the workplace. Designing a work environment ergonomically means to decrease accidental costs and occurrence, injuries and disabilities, to improve well-being of the organization, to optimize organizational performance, to 
increase job satisfaction and productivity, all these in order to decrease physical and cognitive stress on personnel.

\section{Time management and change management}

Bad time management is leads to organizational stress both to employers and to employees, being disorganized. Written to-do lists help to accomplish, prioritize and schedule tasks properly, and to mark them as finished when accomplished. Objectives, duties and activities written down appear to be more tangible and do-able. It should never have more than five items, in order to have more chance to get all the things done, and to feel a greater sense of accomplishment and control. When all the items are completed, one should make another list. It is also important to know how to delegate things, and to make a list of delegated things for co-workers and family members. One should not hesitate to say no when appropriate. Stressed people do not use to ask for help, or to refuse something. When asserting deadlines, always give $20 \%$ more time than you think you need to accomplish the task. It is necessary to set priorities and postpone less important tasks. Major decisions should not me made under pressure. Employees should plan their day to include work breaks which physically or mentally take them away from the office, and not to bring office work home.

Changes are very frequent, especially in contemporary environment. Managers must involve people affected by change in process of changes, not just to inform about the changes. Change management is the process of implementation of changes of a system, in a controlled manner, following a pre-defined framework (model) for reasonable modifications. Principles of change management are: to involve and agree support from people within organizational system; to understand where the organization is at the moment; to understand exactly where, when, and why we want the organization to be, and what are the necessary measures to achieve it; to plan development toward previous principles; and to communicate, involve, enable, and facilitate employees' involvement. Change may represent discontinuity in workplace. Human prefrontal cortex is fast computational device able to hold multiple threads of logic at once so that we can perform fast calculations.

\section{Quality of work living}

Quality of work living is a set of methods, which are: job enrichment, highinvolvement aimed at boosting the satisfaction and productivity, and autonomous working groups. As professional and personal lives are in a strong correlation to each other, human's independency has to cover both work and home. There are eight categories regarding quality of work living: adequate and fair compensations, safe and health working conditions, immediate opportunity to use and develop human capacities, opportunity for continued growth and security, social integration within an organization, constitutionalism within an organization, work and life space, and social relevance of work life. Quality of work living refers to decision participation, restructuring job nature, enhancing workplace environment, and defining reward structure.

In order to explain a model of quality of work living, we will present an empirical study taken from Journal of Social Science 2 (2): 61-67, 2006, "Quality of work life: Implications of career dimensions". They were computed by zero-order correlation (a 
relationship between two variables, ignoring the influence of other variables in prediction; accounting as a redundancy), and by Cronbach's alpha (a measure of reliability of a psychometric instrument).

\section{Descriptive Statistics, zero-order correlation, and Cronbach's alpha of Quality of work living, and the predictor variables}

\begin{tabular}{|ll|}
\hline \multicolumn{2}{l}{ Variables } \\
\hline Y & QWL (10*) \\
\hline$X \square$ & Career satisfaction (10) \\
\hline$X \square$ & Career achievement \\
$(\mathbf{1 3})$ & \\
\hline $\mathrm{X} \square$ & Career balance (15) \\
\hline
\end{tabular}

\begin{tabular}{|l|l|l|l|l|l|}
\hline$\underline{\mathbf{X}}$ & $\mathbf{S}$ & $\mathbf{Y}$ & $\mathbf{X}$ & $\mathbf{X}$ & $\mathbf{X} \square$ \\
\hline 6.3882 & 1.45784 & $0.84 * *$ & & & \\
\hline 6.3905 & 1.11479 & 0.60 & 0.87 & & \\
\hline 6.6766 & 1.41228 & 0.71 & 0.72 & 0.82 & \\
\hline 5.6749 & 1.14991 & 0.14 & 0.34 & 0.25 & 0.91 \\
\hline
\end{tabular}

Source: http://www.uwsp.edu/psych/cw/statmanual/mrcontinuous.html

*Number of items measuring each construct

**Cronbach's alpha

Zero-order coefficients $\mathrm{p}<0.01$

Estimates of coefficients for the model

Table 2

\begin{tabular}{|l|l|l|l|l|l|}
\hline $\begin{array}{l}\text { QWL } \\
\text { dimension }\end{array}$ & $\begin{array}{l}\text { B (Unstandardized } \\
\text { coefficients) }\end{array}$ & $\begin{array}{l}\text { Std. } \\
\text { Error }\end{array}$ & $\begin{array}{l}\text { Beta } \\
\text { (Standardized } \\
\text { coefficients) }\end{array}$ & $\mathbf{t}$ & $\begin{array}{l}\text { p- } \\
\text { value }\end{array}$ \\
\hline $\begin{array}{l}\text { Constant } \\
\text { Career } \\
\text { satisfaction } \\
(\mathbf{X} \square)\end{array}$ & 1.166 & 0.322 & & 3.625 & 0.0001 \\
\hline $\begin{array}{l}\text { Career } \\
\text { achievement } \\
(\mathbf{X} \square)\end{array}$ & 0.365 & 0.056 & 0.136 & 3.202 & 0.001 \\
\hline $\begin{array}{l}\text { Career } \\
\text { balance }(\mathbf{X} \square)\end{array}$ & -0.124 & 0.040 & -0.098 & 7.731 & 0.0001 \\
\hline Source: & $0.178: / W W W . u W s p$ & -3.141 & 0.002 \\
\hline
\end{tabular}

Source: http://www.uwsp.edu/psych/cw/statmanual/mrcontinuous.html $\mathrm{R}=0.791 ; \mathrm{R}^{2}=0.626 ;$ Adj. $\mathrm{R}^{2}=0.622$

Predicator variables are: career satisfaction, career achievement, and career balance. Estimated model: $\mathrm{Y}(\mathrm{QWL})=1.166+0.178(\mathrm{X} \square)+0.365(\mathrm{X} \square)+0.124(\mathrm{X} \square)+E$

After analyzing a problem, we may say that by this empirical study shown, career achievement is the most important determinant of quality of work living, followed by career satisfaction and career balance. Career balance is negative, as this represents the correlation between professional and personal life. Marital status, age, income, education, years of employment, and period of employment at current employer directly affect quality of work living.

Note: This empirical study was done at the University of Malaya, Malaysia, and it is only used to present mathematical computations of quality of work living. 


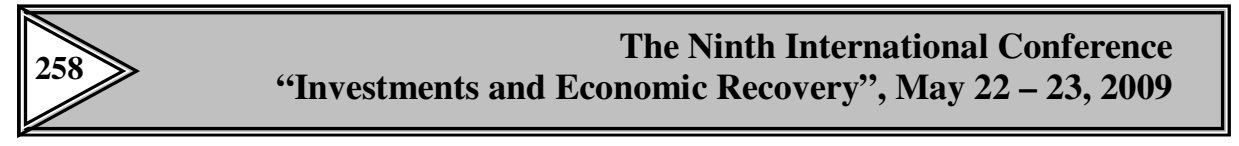

\section{Risk assessment for organizational stress}

Risk assessment can be done when relationship between cause and effect is known, as well as risk psychological nature of the stress process, and uncertainty about the relationship between hazard and harm. Moreover, stressors can have different meaning for different individuals. Some will rate a job as stressful on the basis of how they perceive the objective nature of the work (the stimulus), others will only concern themselves with how it makes them feel (the response). Looking at one's responses to specific stressors can contribute to better understanding of one's particular physical, emotional, and mental resources and limits.

There are four steps in risk assessment process: work-related stressors (psychological and physiological overloading - grouped stressors, damages appearing during working process - having a direct effect over the human body, and also acting as stressors, and dangers - as fear from possible consequences related to tasks accomplishment), stress (as a reaction on exposure to stressors), work-related healthillnesses caused by stress (cardiovascular disorders - artery hypertension, ischemic heart disorders, and cerebral-vascular disorders, chronic unusual respiratory disorders - chronic bronchitis, emphysema, and asthma, locomotoric disorders - lumbar and cervical-brachial syndrome, and behavioral and psychosomatic disorders), workplace risk assessment (workplace with increased risk on health, and workplace with not increased risk on health). All these should be presented in a risk assessment table. Reliable self-reports should be validated through correlation with other factors in behavior, physiology and health. Such kind of measures shall include objective indicators. Objective indicators include: physical thesis such as biochemical, hematological tests, or cardiovascular parameters or measurement of mental performance, and also information from clinical assessments. Beside this we shall use data as levels of absenteeism, accident statistics, or health-related behaviors such as smoking or alcohol consumption.

\section{Legislation}

At the European level, there was reached a voluntary agreement on organizational stress, by organizations. It aims to increase the understanding and awareness of employers and employees about organizational stress. It points the need to be aware of signs that might indicate stress-related problems.

In Serbia there is a law in construction, regarding mobbing or harassment at workplace. There is an actual law on employees protection (Zastita zaposlenih prema Zakonu o radu Republike Srbije, "Sluzbeni glasnik RS", br.24/05, 60/05). Article 12 in this law suppose that employee has rights on safe, and life and health protection at workplace, and rights on protection of one's own integrity. Article 21 forbids disturbance and sexual harassment. By this law, disturbance means any unwanted behavior led by some of basis from Article 18, which suppose forbiddance of discrimination, which has as a target or represents injury dignity of a person who is looking for a job, as well as of the employee, and which provokes fear or creates inimical, humble or insulting environment. Sexual harassment, by this law, is any verbal, nonverbal or physical behavior which has as a target or represents injury dignity of a person who is looking for a job, as well as of the employee

Vol.12, Nr. 1 special/2009

Economia seria Management 
in area of sexual life, and which provokes fear or creates inimical, humble or insulting environment. It states that employer has an obligation to pay certain amount of money for punishment to his employee suffering injuries at workplace or related to work. If employer does not respect law regarding discrimination, punishment amounts to be paid are also mentioned in this law. The law on work does not offer all inclusive protection in case of harassment at workplace. Law on forbiddance of harassment at workplace supposes all inclusive protection regarding employees at all employers, no matter if national or foreign person or entrepreneur, public executives, profitable or non-profitable organizational sector. For-coming legislation in this field should be based on assurance of the entire system of protection from harassment at workplace, as a whole, this offering employees fast and effective protection through short-term execution terms and huge number of temporarily and protection measures.

\section{Methodological and measurement problems}

Some scientist have doubts about existing approaches used to measure stress and also about the political and cultural implications that follow from claims that stress levels are in an extreme rise.

Others have the opinion that so called popularity of stress is driven by cultural change. They say that it is because its broad-based explanatory value, as it can be invoked to account for a variety of negative environmental factors, physical or emotional feelings (Blaug, Kenyon, and Lekhi, 2007). They spouse that legitimization of stress has been added by its prevalence within the media and the professionalization of stress treatments. Some researchers states that stress is a figment of our collective and over-enthusiastic imagination, and that society has built up a complex folklore about stress, which is reinforced by popular culture and media. I do not agree with this theory, because, for example in Serbia stress was not "published" in media until now, or it was, but in a very low quantity, while employees are certainly stressed. The reality is that they do not know much about the phenomenon of stress, they do not know about how to prevent and to relieve it, but they are experiencing stress. This shows that a problem exists, but a people do not know how to cope with it.

\section{Conclusion}

Stress, so called "managerial illness", can be avoided. But we need to change our habits in order to prevent, relieve, and reduce it. Stress at workplace does not only influence employees as a person, but also the organization as a whole, thus it should be treated at both organizational and individual level, in form of organizational arrangement and person's arrangement. Tolerance of stress level differs from person to another. Some people sustain a highly stressful lifestyle or adapt to a series of stressful events easily. But, there are much more of those affected by stress-related illnesses and even accidental injuries. In our region people affected by stress still hesitate to ask for help. Organizational stress is seen as an imaginary fact and people do not quite believe that it can be solved. The problem comes with acknowledgment and education on this point. Employees also do not know their rights. Most of them know only their obligations. Of course, there is also a problem with poor 


The Ninth International Conference
2607 "Investments and Economic Recovery", May 22-23, 2009

management which does not support the employees. While on the other hand, employers seem not to know their obligations.

Both employers and employees should invest in organizational stress management. For the employers a healthy organizational environment with no stress increases organization's productivity and competitiveness. Employees preventing and reducing their stress can achieve better performance in both of their professional and personal field. Organizations and government shall invest in media campaigns promoting awareness of stress and methods of its prevention and relieving.

\section{Bibliography}

Blaug, R., Kenyon, A., Lekhi, R. (2007). Stress at Work, The work foundation, London

Cooper Cary L., Robertson Ivan, (2003). International Review of Industrial and Organizational Psychology 2003, Volume 18, Wiley

Härtel Charmine E. J., Wilfred J. Zerbe, Neal M. Ashkanary, (2005). Emotions in Organizational Behavior, LEA Publishers

Hrnjica, S. (1979). Opšta psihologija sa psihologijom ličnosti, Naucna knjiga, Beograd

Ilanković, V., Ilanković, N., (1995). Restaurativna kineziterapija, Beograd

Jex Steve M., (2002). A Science-Practitioner Approach - Organizational psychology, John Wiley and Sons, INC

Rogelberg Steven G., (2007). Encyclopedia of Industrial and Organizational Psychology, SAGE Publications

Stošljević L., Odović G., (1996). Profesionalno osposobljavanje telesno invalidnih lica, Zavod za udžbenike i nastavna sredstva, Beograd

Top International Business Writers (2002). BUSINESS - The Ultimate Resource

Vitorio di Martino, Mothar Musri (2001). Guidance for the Prevention of Stress and Violence at the Workplace, Ministry of Human Resources Malaysia, Department of Occupational Safety and Health Malaysia

Guidance on Work-Related Stress (2002). European Commission, Directorate-General for Employment and Social Affairs

Research on Work-Related Stress (2000). European Agency for Safety and Health Work www.zdravlje.krstarica.com

http://webspace.ship.edu

Vol.12, Nr. 1 special/2009

Economia seria Management 